\title{
CORRESPONDENCE
}

\section{UPPER SILURIAN GRAPTOLITE ZONES}

SIRs,-The paper by Dr. Earp recently published in the Geological Magazine entitled " Observations on Upper Silurian Graptolites " seems to me to call for comment. The great value of Dr. Straw's work lies in the indications it affords of the changing physical conditions controlling sedimentation in an area of growing orogeny ; this orogeny was episodic, and of greater intensity in some places than others. From my own knowledge of the Builth, Ludlow, and Long Mountain areas it therefore appears to me unlikely from the very nature of things that correlations of any value can be made. The ages of the different " shelly" developments can, however, be approximately determined by reference to the graptolite zones. The physical changes which naturally affect the facies, must be expected also to result in limitation of that free circulation of the waters upon which the widespread distribution of the graptolites depended. That does not affect the validity of the graptolite zones in general. The Ludlovian zones have been recognized in North Wales and occur at intervals along the Welsh Borderland at least as far as Woolhope ; they may therefore be considered well established. I do not think the alternative succession suggested by Dr. Earp for Central Wales would serve its purpose, as it stands, for the "spinose group of the $M$. chimaera type" has a much more extensive vertical range than he seems to realize. Graptolites of this type are characteristic of the greater part of the Lower Ludlovian. They begin in the zone of $M$. nilssoni, attain their maximum development in the zone of $M$. scanicus, pass up into the zone of $M$. $t u$ mescens, and are of rare occurrence in the zone of $M$. leintwardinensis. Moreover they tend to be especially abundant in bands almost to the exclusion of other forms which occur between the bands; therefore they can hardly be chosen as index fossils for the beds between " strata containing $M$. leintwardinensis and strata containing the graptolite assemblages characteristic of the zones of $M$. scanicus and $M$. nilssoni". The assemblage must determine the horizon even if the zone fossil has not been found. The failure to find $M$. scanicus may be due to the tenuity of this fossil, and its tendency to occur in fragments, but its thecae are so unique and characteristic when compressed and viewed in profile, that it is one of the few graptolites that may be identified safely in a fragmentary condition. $M$. salweyi, however, appears to undergo definite evolution towards $M$. leintwardinensis by the gradual acquisition of an hexagonal cell with spines at the median angles of the aperture. If it were possible to determine the evolutional stage reached at any special horizon, it would be most useful. I have not yet succeeded in doing this completely, though I have been at work on these graptolites for a long time. These spinose graptolites are terribly difficult to study, as they are so rarely preserved in profile view; on account of their spines and thin walls they are generally embedded in the rock in such a manner as to induce a degree of tortion in the whole rhabdosome; this I consider to have happened in the case of the fossil described by Dr. Earp as $M$. clunensis, the apparent curvature being clearly connected with the aspect-the more dorsal the 
aspect, the greater the curvature. None of his specimens are seen in true profile, and on the evidence available, I see no reason for separating it from one of the forms of $M$. salweyi.

In the course of my work I have, however, been able to recognize two forms of $M$. salweyi characteristic of definite horizons, and there appear to be a host of transients in the beds between them. The first form is a rather limp one with thin flexed spines which does not range above the zone of $M$. nilssoni, but in the upper part of the zone is accompanied by others with a greater degree of rigidity; in the zones above (those of $M$. scanicus and $M$. tumescens) there are hosts of these transients with different degrees of rigidity accompanying the more definite hexagonal form of both cell and aperture and with a tendency for the spines to be less flexed and to arise at the median angle. In the beds just below those belonging to the zone of $M$. leintwardinensis, there is a very rigid form of $M$. salweyi which comes very close to $M$. leintwardinensis, and was, I think, regarded by Dame Shakespear as an early form of that species, and the beds in which it occurs were placed by her in the zone of $M$. leintwardinensis. In my opinion, the form still has some of the longer spines of $M$. salweyi instead of the shorter stiffer ones which are characteristic of the true $M$. leintwardinensis (Leintwardine Flag type), and I therefore relegated the beds containing them to a lower horizon, and regard the form as a late mutation of salweyi. It is, in any case, not a matter of much moment, since the horizon is known. There are, as noted above, hosts of transients between these two extreme forms, but I cannot yet say whether any is sufficiently stable to rank as a mutation of horizonal value. I hope that may yet prove to be the case.

\section{Characteristic Assemblages of Ludlovian Graptolite Zones}

(Forms of very rare occurrence omitted)

Zone of M. leintwardinensis. M. leintwardinensis and var. incipiens, $M$. $\mathrm{cf}$. ultimus, $M$. salweyi mut.

Zone of $M$. tumescens. $M$. tumuscens and var. minor, $M$. cf. ultimus, $M$. bohemicus (small), $M$. chimaera, $M$. salweyi transients (general absence of $M$. colonus and $M$. dubius).

Zone of $M$. scanicus. M. scanicus, M. varians var. pumilus (C), M. roemeri, $M$. dubius. $M$. tumescens, $M$. chimaera, and var, semispinosus, $M$. salweyi, M. nilssoni, M. bohemicus (small) (absence of all lobate Monograpti).

Zone of $M$. nilssoni. $M$. nilssoni, $M$. colonus, $M$. comis, $M$. crinitus, $M$. vulgaris (2 vars.), $M$. roemeri, $M$. bohemicus (2 forms) $M$. dubius (2 forms), $M$. chimaera, and var. semispinosus, $M$. salweyi (at least 2 forms), $M$. varians var., $M$. uncinatus var. orbatus and var. micropoma, Gothogr. spinosus.

Zone of $M$. vulgaris. M. vulgaris, M. dubius (small), M. flemingii, Gothogr. nassa.

The fauna of the zone of $M$. nilssoni is rich and varied, but with some difference in relative abundance of certain graptolites in the higher and lower beds. M. salweyi (limp form) is of rather rare occurrence in the higher beds, but fairly abundant in the lower. The large forms of both $M$. bohemicus and $M$. dubius seem also to be commoner at the lower horizon where $M$. vulgaris vars. $a$ and $\beta$ also occur. In the higher beds, $M$. varians is more abundant and also $M$. roemeri (which is still more abundant in the zone of $M$. scanicus), $M$. chimaera, and $M$. salweyi 
transients, and an occasional $M$. scanicus are also found in association with $M$. uncinatus var. orbatus and var. micropoma and other characteristic graptolites of the Nilssoni zone which are not found in the zone of $M$. scanicus.

Under the conditions prevailing in the Welsh Borderland towards the close of Silurian time, any part of this succession is liable to be replaced to a greater or lesser extent by a non-graptolitic facies. Overlap also occurs.

Sedgwick Museum,

Gertrude L. Elles.

Cambridge.

6th November, 1944.

\section{THE TREDINGTON “ICHTHYOSAUR"}

SiRS,-In 1913, the late Canon Bazeley recorded " bones of an Ichthyosaurus or other saurian" in a slab of Lias Limestone flooring the porch of Tredington Church, south of Tewkesbury, Gloucestershire.' Since then the same specimen has twice been described as an Ichthyosaurus 9 feet long. ${ }^{2,3}$ A year ago it was similarly described yet again, in Country Life, and the account was accompanied by a photograph of a heel-ball rubbing of the supposed saurian. ${ }^{4}$ Since the illustration clearly was of no fossil reptile, one of us took the opportunity of visiting Tredington and examining the specimen. The portion figured as a $9 \mathrm{ft}$. saurian is merely a network of joints and other cracks ; but, within this area, as well as outside it, are a few scattered saurian bones, doubtless those seen and recorded by Canon Bazeley. But Bazeley's report continues : " how they (the bones) came to be there I know not." Considering that Tredington lies on the Lower Lias, and that a few miles away, at Boddington, old quarries are noted by the Geological Survey, ${ }^{3}$ there is no call for the remark; still less for the curious statement in the Country Life article : "The stone, of the Lias formation, ... was, presumably, brought from the near-by Cotteswolds." Thus a fabric of mistakes has been built upon a few grains of fact. It is hoped that this latter may remove misunderstanding and, perhaps, save some geologist an unnecessary journey.

Lias Lea,

Charmouth,

THE UNIVERSITY,

BRISTOL.

10 th October, 1944.

1 W. Bazeley, Trans. Bristol and Gloucestershire Arch. Soc., vol. xxxvi, for 1913, p. 37.

2 J. C. Cox, 1920, Gloucestershire, 3rd edition, Methuen and Co., p. 213.

' W. H. Bird (no date), Old Gloucestershire Churches, E. G. Burrow and Co., p. 182.

A. E. Knight, 1943, Country Life for 20th August, p. 342.

H. B. Woodward, 1893, Lias of England and Wales, Mem. Geol. Surv., 